\title{
Economic aspects of biomass market development in Ukraine
}

\author{
Oleg Kucher ${ }^{1, *}$, Liliia Prokopchuk ${ }^{1}$ \\ ${ }^{1}$ State Agrarian and Engineering University in Podilia, Kamianets-Podilskyi, Ukraine
}

\begin{abstract}
The article considers the state and prospects of bioenergetics development in the context of rationalization of the use of available natural resource potential of Ukraine. It is determined that one of the most perspective renewable energy sources is biomass, the main component of which is by-product of plant growing. It is noted that the use of by-products of crop production for receiving heat energy is a rational way to utilize their surpluses that are not used for other purposes of agriculture. The existing resource potential of this agricultural biomass and source of its obtainment were characterized. An estimation of the potential of this type of biomass up to 2025 , which can be used for thermal power engineering was made. It was noted that the effective use of biomass potential of agricultural enterprises is possible in case of creation of the appropriate mechanism, a set of management decisions aimed at solving the energy issue. The structure of the formation of the economic model of the influence of factors on the state of the use of by-products of crop production in thermal power engineering was proposed.
\end{abstract}

\section{Introduction}

In recent years, due to the global energy crisis, agricultural products and waste have begun to be considered as fuel resources. Crop production residues are produced and accumulated in enterprises that process crops. In Ukraine, the practice of using by-products of crop production for heating began in 2000 with the installation of a straw burning boiler with a installed capacity of $980 \mathrm{~kW} / \mathrm{h}$. The technology is based on Danish experience. Soon after, the Ukrainian company UTEM began to produce similar boilers under a licensing agreement with the Danish company Passat Energy.

Ukraine belongs to countries with high bioenergy potential. Prospects for bioenergy development in Ukraine are defined by the National Renewable Energy Action Plan (NPDWE) for the period up to 2020, approved by the Cabinet of Ministers of Ukraine on October 1, 2014. According to the plan till 2020 bioenergy should reach the level of replacement of natural gas at an amount of 8.3 billion cubic meters per year. [1]. The main components of this potential are by-products of plant growing, which includes straw of cereals and rape, corn stalks, sunflower, etc.

\footnotetext{
* Corresponding author: kucheroleg68@gmail.com
} 


\section{Methodology and purpose of the study}

Analysis of the state of crop production in enterprises shows that they form average and high levels of yield, have high economic indicators. However, the possibilities for the use of crop production by-products are not given sufficient attention. Therefore, the study of the state of use and potential of by-products of crops is extremely relevant.

In the process of this study, the following methodological approaches were used: the study of dynamics of volumes of primary vegetable wastes as a component of biomass and directions of their agricultural and energy use for the period of 2013-2017 years has been carried out.

To present the results of the study were used:

1. Table, graphic, and calculation methods, which allowed to analyze the dynamics of volumes of by-products of crop production in 2013-2017 years.

2 . The analysis of biomass volumes for thermal power engineering was carried out with the help of an in-depth statistical method taking into account the directions of use of primary plant waste.

3. To assess the potential of primary plant waste, a resource-based approach based on exploration of the resource base and energy and non-energy use issues has been used.

4. The forecasting method allowed calculating the amount of by-products of crop production for the production of thermal energy by 2025 .

5. Using a modeling method, a group of factors influencing the state of the use of crop production waste in the heat power engineering

The aim of the study is to provide a complete and reliable assessment of the potential of crop production by-products, which can be used for energy purposes.

\section{Results of the study}

\subsection{Current state of the resource base of by-products of crop production as raw materials for energy use}

The basis for the development of bioenergy is the availability of the raw material base. In recent years, accelerated bioenergy development has taken place in Ukraine, which needs to study the resource base of biomass as raw material for the production of solid fuels. It is necessary to have clear data on the annual volume of production of by-products of crop production to do this, as well as of that part which is available for energy use.

Biomass is one of the most promising renewable energy sources, but its use in Ukraine is limited, despite the positive trend in recent years. The main component of the potential of solid biomass of agricultural origin is vegetable waste. For the possibility of using energy, it is necessary to ensure the collection of appropriate waste.

The main objective of agrarian production is to obtain the maximum grain yield as the main commodity output. By-products are straw, stems, pots, husk whose volumes are determined by the coefficient of output of agricultural biomass, representing the ratio in the biomass of the bulk and the main products. The value of this coefficient is given in Table 1 $[2]$.

Ukraine has a large number of by-products of crop production due to the highly developed agricultural sector. The grain and non-grain (straw) grain share is close to the general production of grain crops in Ukraine. In the process of harvesting the grain part of the culture is separated from the stem, and the further method of straw harvest depends on the technology used. A part of the straw remains in the shape of a stubble in the field and later it breaks into the ground. 
The main factors that influence the volumes of annual crop production are crop areas, crop yields and gross taxes. Using statistical data [3] we will conduct a study of the main indicators determining the amount of received by-products of potential crops for the period 2013-2017.

Table 1. Dynamics of production of grain and primary plant waste, mln tons.

\begin{tabular}{|c|c|c|c|c|c|c|c|c|c|c|c|}
\hline \multirow[b]{2}{*}{ 气̊̀ } & \multirow[b]{2}{*}{ 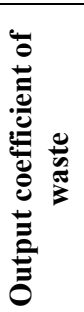 } & \multicolumn{2}{|c|}{2013} & \multicolumn{2}{|c|}{2014} & \multicolumn{2}{|c|}{2015} & \multicolumn{2}{|c|}{2016} & \multicolumn{2}{|c|}{2017} \\
\hline & & 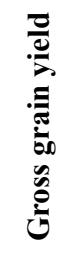 & 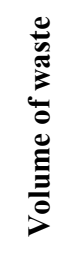 & 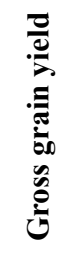 & 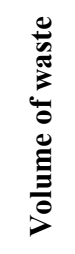 & 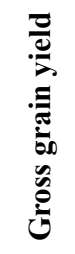 & 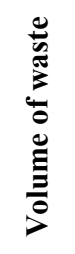 & 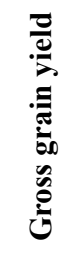 & 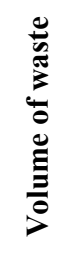 & 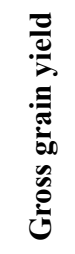 & 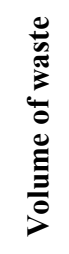 \\
\hline Wheat & 1,0 & 22,3 & 22,3 & 24,1 & 24,1 & 26,5 & 26,5 & 26,0 & 26,0 & 26,2 & 26,2 \\
\hline Grain & 1,3 & 0,6 & 0,8 & 0,5 & 0,6 & 0,4 & 0,5 & 0,4 & 0,5 & 0,5 & 0,7 \\
\hline Barley & 0,8 & 7,6 & 6,0 & 9,0 & 0,7 & 8,3 & 0,7 & 9,4 & 0,8 & 8,3 & 6,6 \\
\hline Oats & 1,0 & 0,5 & 0,5 & 0,6 & 0,6 & 0,5 & 0,5 & 0,5 & 0,5 & 0,5 & 0,5 \\
\hline Millet & 0,8 & 0,1 & 0,1 & 0,2 & 0,1 & 0,2 & 0,2 & 0,2 & 0,2 & 0,1 & 0,1 \\
\hline Buckwheat & 0,9 & 0,2 & 0,2 & 0,2 & 0,2 & 0,1 & 0,1 & 0,2 & 0,2 & 0,2 & 0,2 \\
\hline \begin{tabular}{|l|} 
Corn for \\
grain \\
(stems)
\end{tabular} & 1,3 & 30,9 & 40,2 & 28,5 & 37,6 & 23,3 & 30,3 & 28,1 & 36,5 & 24,7 & 32,1 \\
\hline $\begin{array}{l}\text { Sunflower } \\
\text { (stems) }\end{array}$ & 1,9 & 11,1 & 21,0 & 10,1 & 19,2 & 11,2 & 21,2 & 13,6 & 25,9 & 12,2 & 23,2 \\
\hline Soybean & 0,9 & 2,8 & 2,5 & 3,9 & 3,5 & 3,9 & 3,6 & 4,3 & 3,8 & 3,9 & 3,5 \\
\hline Rape & 2,0 & 2,4 & 4,7 & 2,2 & 4,4 & 1,7 & 3,5 & 1,2 & 2,3 & 2,2 & 4,4 \\
\hline Total & & 78,5 & 98,3 & 79,3 & 91,0 & 76,1 & 87,1 & 83,9 & 96,7 & 78,8 & 91,6 \\
\hline
\end{tabular}

Source: Formed by the author [3, 4].

To determine the yield of crop production by-products is a widespread approach to utilizing the Waste Factor [4], which is the ratio of the value of straw or stem crop yields to the grain yield. The calculations showed that most of the plant waste in agriculture comes from the production of corn for grain, wheat and sunflower, and slightly less for the production of other grains (Table 1).

Some of the crop wastes received, in particular straw, of cereals are used for agricultural needs and for processing in solid biofuels: bales, rolls, fuel pellets (pellets), fuel briquettes. Biomass is a convenient product, which, due to the consolidation of raw materials, 4-5 times more conducive to more efficient logistics and storage.

In order to determine the available quantity of by-products of crop production for use, account must be taken of the losses of the technological process of harvesting of cereals. Taking into account the coefficient of losses $\mathrm{Kvtr}=0,1$, the available amount of straw is $90 \%$ of the gross amount.

With the available amount of primary plant-based waste, large volumes are used for livestock needs as litter and rough livestock feed, and in crop production as organic fertilizer. For litter, animals are mainly used for straw wheat, barley and rye. For the amount of straw for litter on the 1 head of cattle, we accept its average value of 1,825 t/year, and the planned rules for the introduction of straw as a fertilizer are $1 \mathrm{t}$ per 1 hectare of crops [5]. 
The number of straw for livestock needs depends on the cattle population, and the amount of straw used as fertilizer depends on the area from which the harvest is harvested. The surplus of by-products of crop production can be used in thermal energy (Table 2).

Table 2. Theoretical amount of primary vegetable waste in directions of use.

\begin{tabular}{|c|c|c|c|c|c|}
\hline Indicators & 2013 & 2014 & 2015 & 2016 & 2017 \\
\hline $\begin{array}{l}\text { Gross collection of by-products of } \\
\text { crop production, ths. tons }\end{array}$ & 92984,6 & 126078,7 & 87117,0 & 96721,0 & 91455,8 \\
\hline $\begin{array}{l}\text { Available quantity of by-products of } \\
\text { plant growing, ths. tons }\end{array}$ & 83687 & 113471 & 78405 & 87049 & 82310 \\
\hline \multicolumn{6}{|c|}{ The use of straw in livestock breeding 1,825 tons per year per head of cattle } \\
\hline Number of cattle, ths. head & 4534,0 & 3884,0 & 3750,3 & 3682,3 & 3530,8 \\
\hline $\begin{array}{l}\text { Average number of straw for litter, } \\
\text { ths. tons }\end{array}$ & 8274 & 7088 & 6844 & 6725 & 6444 \\
\hline Percentage for bedding, $\%$ & 10 & 6 & 9 & 8 & 8 \\
\hline \multicolumn{6}{|c|}{ To apply as fertilizer 1 ton per 1 hectare } \\
\hline $\begin{array}{l}\text { The area from which the crop is } \\
\text { harvested thousand hectares }\end{array}$ & 15804,4 & 14627,3 & 14640,9 & 14337,1 & 14560,3 \\
\hline $\begin{array}{l}\text { Number of straw for fertilizers, ths. } \\
\text { tons }\end{array}$ & 15804,4 & 14627,3 & 14640,9 & 14337,1 & 14560,3 \\
\hline Percentage of fertilizers, $\%$ & 19 & 13 & 19 & 16 & 18 \\
\hline \multicolumn{6}{|c|}{ For energy use } \\
\hline $\begin{array}{l}\text { Excess of crop production by- } \\
\text { products, ths. tons }\end{array}$ & 59609 & 91756 & 56920 & 65987 & 61306 \\
\hline Percentage for energy goals, $\%$ & 71 & 81 & 72 & 76 & 74 \\
\hline
\end{tabular}

Source: Authors' own calculations based on [3].

The performed calculations showed that during the period under investigation the available quantity of by-products of plant growing averaged over 90 million tons. In livestock farming, about $9 \%$ of straw was used and as organic fertilizer to maintain fertility of soils by about $17 \%$. The surplus of crop production by-products for energy use was within $84 \%$ and amounted to an average of 67 million tons. It is a sufficient source of raw materials for use in energy purposes.

It should be noted that biomass of agricultural origin (straw of cereals and rapeseed, byproducts of corn production for grain and sunflower) remains the main component of the energy potential of biomass in Ukraine. According to 2017, the economic potential of these types of biomass, available for energy production, is almost 8 million tons of oil equivalent, which is $38 \%$ of the total biomass potential and equals 20.9 million tons of oilseed. (Table 3 ). The full use of the energy potential of agrobiomass can cover about $18 \%$ of the final energy consumption in Ukraine, which in 2017 amounted to 50.1 million tons. [6].

Table 3. Energy potential of by-products of crop production in 2017.

\begin{tabular}{|l|c|c|c|}
\hline \multicolumn{1}{|c|}{ Biomass type } & $\begin{array}{c}\text { Theoretical } \\
\text { potential, million } \\
\text { tons }\end{array}$ & $\begin{array}{c}\text { Potential available for energy } \\
\text { The share of } \\
\text { theoretical } \\
\text { potential, \% }\end{array}$ & $\begin{array}{c}\text { MIn. tons of } \\
\text { oil equivalent }\end{array}$ \\
\hline Straw of grain crops & 35,6 & 30 & 3,65 \\
\hline Straw of rape & 3,9 & 40 & 0,54 \\
\hline $\begin{array}{l}\text { By-products of corn production on grain } \\
\text { stems, rods) }\end{array}$ & 32,1 & 40 & 2,45 \\
\hline By-products of sunflower (stems, baskets) & 23,2 & 40 & 1,33 \\
\hline
\end{tabular}

Source: Formed by authors on the basis of [6]. 
An analysis of the use of energy potential has shown that the most expedient is to increase the production of energy from by-products of crop production, since the current level of use of the energy potential of these types of biomass in the country is very low - from 0 to $2-3 \%$ depending on the specific species (Table 4). Given the growth of grain crop yields, in particular wheat and maize for grain to European levels, it is possible to predict a further increase in the energy potential of this type of biomass in the coming years. With this approach, its potential may increase from the current 8 million tons of fuel oil / year to 11,3 million tons of fuel oil per year [6].

Table 4. Use of energy potential of by-products of crop production in 2017.

\begin{tabular}{|c|c|c|c|c|}
\hline \multirow{2}{*}{ Biomass type and direction of use } & \multirow{2}{*}{$\begin{array}{c}\text { Potential } \\
\text { available for } \\
\text { energy, } \\
\text { thousand tons }\end{array}$} & \multicolumn{2}{|c|}{$\begin{array}{l}\text { The volume that is } \\
\text { already being used for } \\
\text { energy needs }\end{array}$} & \multirow{2}{*}{$\begin{array}{c}\text { Share of the use } \\
\text { of Total } \\
\text { Potential,\% }\end{array}$} \\
\hline & & $\begin{array}{c}\text { thousand } \\
\text { tons }\end{array}$ & $\begin{array}{l}\text { thousand } \\
\text { tons of oil } \\
\text { equivalent }\end{array}$ & \\
\hline Straw of cereals / rape & 12258 & 371 & 130 & 3,0 \\
\hline Incl - burning (bales) & & 200 & 68 & 1,6 \\
\hline -production and burning pellets & & 155 & 55 & 1,3 \\
\hline - production and export of pellets & & 0,97 & 0,35 & 0,01 \\
\hline - production and burning of briquettes & & 15 & 5,5 & 0,1 \\
\hline Stems, corn rods & 12828 & 15 & 5,0 & 0,1 \\
\hline Stems, sunflower baskets & 9299 & 0 & 0 & 0,0 \\
\hline
\end{tabular}

Source: Formed by authors on the basis of [6].

The use of by-products of crop production for thermal energy is a rational way to utilize their surpluses that are not used for other purposes of agriculture. Straw and stems of plants represent an environmentally friendly source of energy since they are $\mathrm{CO}_{2}$-neutral. It is worth noting that in the process of straw growth, the same amount of $\mathrm{CO}_{2}$ released by its combustion is absorbed. This is a fairly widespread local fuel in agricultural areas. The by-products of crop production are the residual product of grain production and this makes it relatively cheap fuel compared to traditional ones. In addition, in the process of its combustion, in the form of a by-product, an ash is produced which can bring additional income if it is used as a fertilizer for plants in fields.

The life cycle of biofuels from agricultural biomass starts in the field, and therefore it is important to encourage agro-producers to create sustainable conditions for bioenergy projects and to create appropriate conditions for harvesting and supply of specified volumes of energy raw materials.

\subsection{Potential for the development of a resource base for the energy use of by- products of crop production}

The sector of bioenergy in Ukraine has the greatest potential for development. This is due to the peculiarities of the climate, the potential of the agrarian sector and the availability of the necessary labor force. Such types of biomass as agricultural crops have the greatest energy potential. The main by-product of crop production is straw, the surplus of which can be attracted to the fuel and energy balance. The question of assessing the straw potential became relevant with the emergence of demand for it. Biomass is one of the most promising renewable energy sources, but its use in Ukraine is limited, despite the positive trend in recent years. 
In the structure of biomass, an important place is given to by-products of plant growing. Correct and reliable assessment of the potential of biomass in agriculture is an important prerequisite for its effective use in bioenergy. The dynamics of the volumes of primary plant products for the production of thermal energy for the future can be determined on the basis of analysis of statistical data and the rate of growth (decline) $K_{B}[7]$.

$$
K_{B}=\left(B_{1}-B_{0}\right) \div B_{0}
$$

Substituting the relevant indicators in the formula, we obtain coefficients that characterize growth or decline in the volume of by-products of plant production for the relevant periods (Table 5).

Table 5. Coefficients for determining the potential of a side crop production for the production of thermal energy.

\begin{tabular}{|c|c|c|c|c|}
\hline Years & Symbols & $\begin{array}{c}\text { Production } \\
\text { output, } \\
\text { thousand tons }\end{array}$ & Rate of growth rate & $\begin{array}{l}\text { Average rate of } \\
\text { growth }\end{array}$ \\
\hline 2013 & $\mathrm{~B}_{0}$ & 83687 & & \multirow{5}{*}{$\begin{array}{l}\left(\mathrm{K}_{\mathrm{B} 1}-\mathrm{K}_{\mathrm{B} 2}+\mathrm{K}_{\mathrm{B} 3-}\right. \\
\left.\mathrm{K}_{\mathrm{B} 4}\right): 4=0,11\end{array}$} \\
\hline 2014 & $\mathrm{~B}_{1}$ & 113471 & $K_{\mathrm{B} 1}=(113471-83687) \div 83687=0,36$ & \\
\hline 2015 & $\mathrm{~B}_{2}$ & 78405 & $K_{\mathrm{B} 2}=(78405-113471) \div 113471=-0,31$ & \\
\hline 2016 & $\mathrm{~B}_{3}$ & 87049 & $K_{\mathrm{B} 3}=(87049-78405) \div 78405=0,11$ & \\
\hline 2017 & $\mathrm{~B}_{4}$ & 82310 & $\kappa_{\mathrm{B} 4}=(82310-87049) \div 87049=-0,05$ & \\
\hline
\end{tabular}

Source: Own calculations by authors based on [3]

Based on the results obtained, the average rate of growth of volumes of by-products of crop production for the study period is equal to 0.11 or $11 \%$. The obtained indicator shows that volumes of by-products of crop production in 2013-2017 years tended to increase. Using this indicator, a calculation was made for the period up to 2025 (Fig. 1). According to the results obtained in 2025, the amount of crop waste for the production of thermal energy can be about 190 million tons. Consequently, thanks to favorable natural conditions and high soil fertility, Ukraine has a great potential for biomass available for energy use.

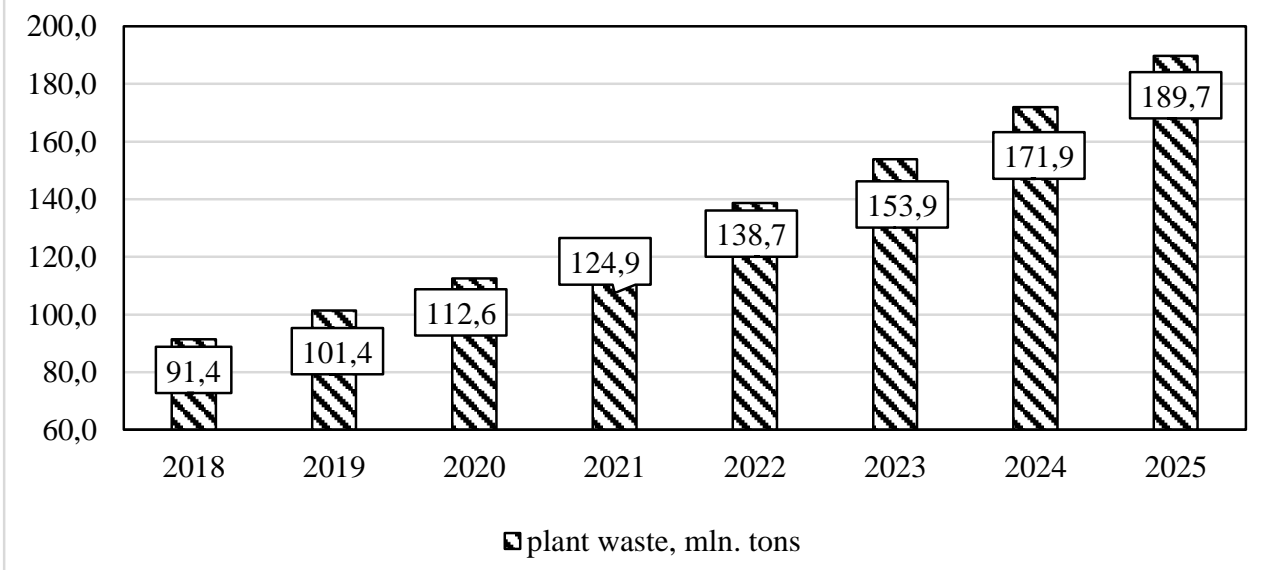

Fig. 1. Potential of biomass available for energy use.

Source: own calculations by the authors 
According to the forecast of the Bioenergy Association of Ukraine, 90\% of biomass and waste energy by 2035 will be provided by solid biomass. In fig. 2 The results of the estimation of the share of crop wastes, in particular straw and stems, for the production of heat energy in Ukraine with a forecast of 2035, are presented. From the above results, it is evident that in order to achieve the set goals in the coming years broad involvement of agricultural byproducts (straw, corn / sunflower stems) ) to the fuel and energy balance of the country.

In order to achieve the projected indicators, the organization of harvesting of by-products and the use of biomass potential of agricultural enterprises is possible in the event of the creation of a suitable mechanism, a set of management decisions aimed at solving the energy issue. In fig. 3 the structure of the concept of forming an economic model of the influence of factors on the state of the use of by-products of crop production is proposed. In the structure of the model two components are considered: analytical support and factors influencing the development of the market of by-products of crop production and their justification.

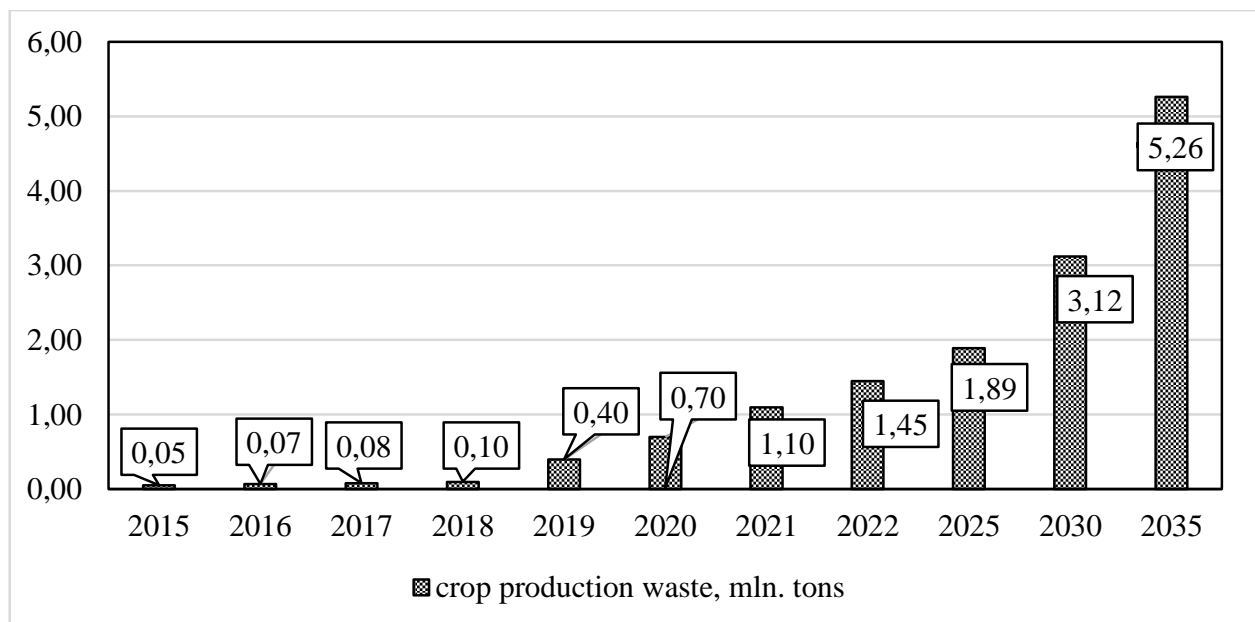

Fig. 2. Volume of biofuel consumption from by-products of plant growing.

Source: Formed by authors on the basis of [2].

Analytical support should form a position on the needs and market demands for crop production side products for heat production and analyze all the components of this process for the establishment of the specified activity.

The justification of the factors influencing the development of the market for crop production side effects requires research, analysis, consideration of opportunities and requirements and the harmonization of positions in the context of all factors of influence to ensure the effectiveness of this activity.

By-products of crop production are potential raw materials for the production of biofuels. Biofuel technologies that exist today enable it to be processed into valuable fuel pellets and briquettes.

The Effect of Using Alternative Fuels from Crop Waste:

1. Creation of environmentally friendly, non-waste production;

2. Reduced production cost;

3. Cost-effective use of plant wastes;

4. Savings of budget funds allocated for purchase of fuel for municipal boilers;

5. Small business development;

6. Creation of new workplaces in villages; 
An important argument for using straw for energy purposes is that the products of combustion are $\mathrm{CO}_{2}$-neutral - thus, the $\mathrm{CO}_{2}$ content in the atmosphere does not increase, and hence the greenhouse effect is not increased $[8,9]$.

Experts estimate that in the coming years, Ukraine can increase the production of grain and oilseeds to 100 million tons a year. As early as in 2018, Ukraine collected 35.8 million tons of corn for grain at a yield of 78.4 centners per hectare and sunflower 14.2 million tons at a yield of $23 \mathrm{c} / \mathrm{ha}$. [6]. However, still unresolved are the questions about the possibility and optimal approaches to harvesting by-products of plant production. The main barrier is the lack of equipment for harvesting of by-products of crop production in agricultural producers. The main objective of the agrarian sector of the economy is to maximize profits from the production of basic commodity products. In order to assure the collection of by-products, they need to invest in specialized equipment and use additional resources [10].

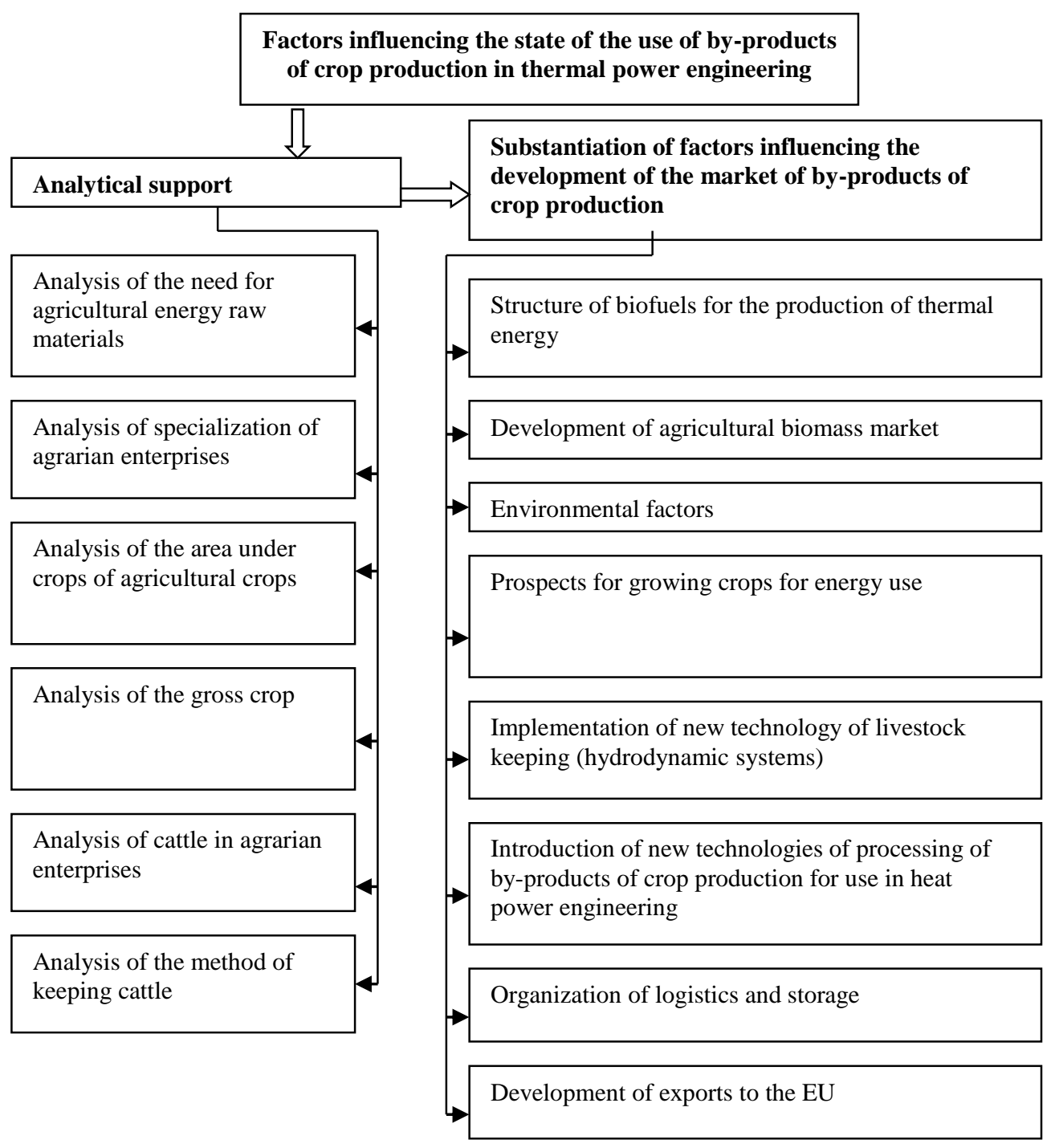

Fig. 3. Factors influencing the state of the use of by-products of crop production.

Developed by authors 
In this regard, agrarian enterprises should be considered as the real producer and supplier of fuel raw materials for the country's energy needs, and bioenergy should occupy a separate niche in the structure of the agro-industrial complex. According to the most realistic scenario, an increase in the amount of plant waste will occur both through the use of new high-yield varieties of food crops and new technologies for the harvesting of by-products of crop production for energy use. Thanks to the study of EU experience in this field and the introduction of new technologies for agricultural production in Ukraine, one can expect rapid development of bioenergy component of agrarian production in the nearest future.

\section{Conclusions}

Ukraine has a great potential for agricultural waste, which is cheap and affordable raw material for energy production. However, most of the by-products of crop production remain in the fields or burned without bringing any benefits.

Technologies of energy use of agricultural biomass are in Ukraine at the initial stage of development, but, with the creation of appropriate conditions, can be implemented in the coming years.

Summarizing the results of the study, one can note the following key positions in the issue of harvesting and the use of by-products of crop production in the energy sector:

- the share of small hydropower in the total installed capacity of renewable energy objects remains insignificant, but the natural potential of its development is not yet fully realized;

- the energy use of plant waste is an additional opportunity to intensify agriculture and increase its profitability, as well as one of the ways to reduce the country's energy dependence.

For implementation of projects on energy use of by-products of crop production it is necessary:

- within the framework of the programs of the Ministry of Agrarian Policy in support of farmers, procurement and use of crop production for energy needs should receive targeted state support;

- in the strategy of bioenergy development in Ukraine to allocate a separate section on the use of by-products of plant growing;

- to concentrate efforts of scientists and practitioners on the development of basic technologies and approaches for the organization of priority supply chains for domestic conditions;

Increasing the potential of bioenergy from plant wastes will enable not only to partially replace the consumption of fossil fuels, but also to increase the export of biofuels to EU countries.

\section{References}

1. The National Renewable Energy Action Plan for the period up to 2020. http://zakon2.rada.gov.ua/laws/show/902-2014-\%D1\%80 (2014)

2. Practical manual on the use of biomass as a fuel in ... http://bioenergy.in.ua/media/filer_public/f5/9c/f59c3f7f-8eca-4b6d-94cdffda1150f3ae/biofin.pdf (2017)

3. Agriculture of Ukraine agriculture of ukraine - State ... http://www.ukrstat.gov.ua/druk/publicat/kat_u/2018/zb/09/zb_sg2017_pdf.pdf

4. G. Morozov, E. Fedorchuk Evaluation of potential bioenergy plant waste and energy crops in agriculture Kherson region. Scientific Herald of Kherson State University Issue 10. Part 3. p. 111-117 (2015) 
5. S. Klyus The portion of the straw and plant waste for energy production of renewable energy. No 4 - P. 82-85 (2013) http://nbuv.gov.ua/UJRN/vien_2013_4_15

6. Barriers to the production of energy from agrobiomas - Bioenergy ... http://uabio.org/img/files/docs/position-paper-uabio-18-ua.pdf (2019)

7. Method of calculation of indicators of financial condition of the enterprise https://studopedia.su/16_170023_metodika-rozrahunku-pokaznikiv-finansovogo-stanupidpriiemstva.html ... (2015)

8. Using straw - News - News - PÖTTINGER https://www.poettinger.at/en_us/Newsroom/Artikel/6673/ (2013)

9. Kuznetsova A. The Use of Straw in Ukraine - opporturities and prospects - apd GermanUkrainian agrarian dialogue. The institute of economic research and political advisory. https://www.apd-ukraine.de/images/AgPP_31_ukr.pdf (2010)

10. Heletuha H., Dragniev S., Zheliezna T. Bioenergy association of Ukraine. Analysis of the barriers of the production of the agro biomass energy in Ukraine. http://www.uabio.org/img/files/docs/position-paper-uabio-21-ua.pdf . (2019) 